\title{
Agricultural sciences in Chile: Institutions, human resources, investment and scientific productivity
}

\author{
Alejandro del Pozo ${ }^{1 *}$, Alejandra Engler ${ }^{2,3}$, and Francisco Meza ${ }^{4,5}$ \\ ${ }^{1}$ Universidad de Talca, Facultad de Ciencias Agrarias, Centro de Mejoramiento Genético y Fenómica Vegetal, Av. Lircay s/n, Talca, \\ Chile. *Corresponding author (adelpozolira@gmail.com). \\ ${ }^{2}$ Pontificia Universidad Católica de Chile, Facultad de Agronomía e Ingeniería Forestal, Departamento de Economía Agraria, \\ Av. Vicuña Mackenna 4860, Santiago, Chile. \\ ${ }^{3}$ Núcleo Milenio CESIEP, Av. Vicuña Mackenna 4860, Santiago, Chile. \\ ${ }^{4}$ Pontificia Universidad Católica de Chile, Centro Interdisciplinario de Cambio Global, Av. Vicuña Mackenna 4860, Santiago, Chile. \\ ${ }^{5}$ Pontificia Universidad Católica de Chile, Facultad de Agronomía e Ingeniería Forestal, Departamento de Ecosistemas y Medio \\ Ambiente, Av. Vicuña Mackenna 4860, Santiago, Chile.
}

Received: 26 April 2021; Accepted: 12 August 2021; doi:10.4067/S0718-58392021000400664

\begin{abstract}
Agricultural science in Chile began in 1881 with the establishment of the Agronomic Station of the National Society of Agriculture (SNA). In this article we described the history and evolution of research and development (R+D) and human capital training in this field. The main research institution, in terms of territory coverage and human resources, is the Instituto de Investigaciones Agropecuarias (INIA), along with five regional research centers, specialized in different aspect of agricultural science, and 20 schools of agriculture and 11 doctoral programs associated to different universities. Public investment in agricultural R+D is provided by the Ministry of Agriculture, Ministry of Science and Technology, Ministry of Economy and Regional Governments, reaching around US\$200 million in the last decade. The number of researchers in agricultural science is $\sim 40$ per million of inhabitants ( $\sim 800$ in total). An average of 140 projects per year are financed in agriculture $\mathrm{R}+\mathrm{D}$ by different funding agencies. The scientific productivity was estimated in $\sim 0.45$ articles (Scopus) per researcher. It is concluded that, although significant progress has been made the last decades, there is still a reduced number of researchers and insufficient investment to face urgent challenges of the agricultural sector in Chile.
\end{abstract}

Key words: Agricultural research, doctoral programs, funding agencies, publications, $\mathrm{R}+\mathrm{D}$ projects.

\section{INTRODUCTION}

According to Encyclopedia Britannica, agricultural science is "a discipline that encompasses the group of sciences dealing with food and fiber production and processing. They include the technologies of soil management, crop cultivation and harvesting, animal production, and the processing of plant and animal products for human consumption and use". It is a multidisciplinary science that brings together biology, chemistry, physics, mathematics, economy and social sciences, to improve and understand agricultural production and processing. Veterinary science, dealing with the health and welfare of animals, but not animal science and production, is excluded from the definition.

Perhaps, the first agricultural scientist was Justus von Liebig of Darmstadt from Germany (1803-1873). His book, "Organic chemistry in its applications to agriculture and physiology", published in 1840, was the beginning of a more systematic application of the scientific method to agricultural problems. In England, the Rothamsted Experimental Station was founded by John Bennet Lawes in 1843 who, in association with Joseph Henry Gilbert, initiated the world's most recognized long-term field experiments (Rothamsted, 2019). Shortly after in the USA, the first systematic research initiatives were undertaken by the Department of Agriculture (USDA) by creating Agricultural Experiment Stations in 16 states, between 1875 and 1885. In Chile, the first experimental station in agriculture was set up in 1876 by the National Society of Agriculture (Sociedad Nacional de Agricultura, SNA), a private organization of farmers founded in 1832 (SNA, 2014), which was contemporary to the ones set up by USDA. It was not until 1931, 50 yr later, that the State 
of Chile was directly involved in the promotion and development of the agricultural science with the creation of the Department of Genetics and Crop Science, which was a branch of the Ministry of Agriculture.

In relation to the country area (75.67 million ha) the cultivated land in Chile is limited, around 2.123 million ha, of which 1.303 million ha are used for annual and permanent crops, distributed as follow: 0.696 million ha of annual crops, 0.350 million ha for fruit trees, 0.136 million ha for vineyards and 0.077 million ha of horticulture crop. In addition, there are 0.401 million ha for forage pastures and 0.419 million ha are fallow land (ODEPA, 2019). In the last decades, Chilean governments have foster policies whose aim is to position Chile as a "Potencia Agroalimentaria" (World Agrifood Leader). In this sense, the Ministry of Agriculture, in partnership with exporters and producer associations, have directed resources to the promotion of Chilean agricultural products, specially, fresh fruits and wines worldwide, and have invested in preventing the introduction of pests and diseases, maintaining high sanitary standards that are compatible with an export-oriented agriculture. Indeed, Chile is considered one of the top exporters of fresh fruits and wine worldwide; the primary agricultural sector represented only $2.4 \%$ of the gross domestic product (ODEPA, 2019), but when adding the food processing industry, it reached up to $14.36 \%$ in 2015 (ODEPA, 2019). Moreover, agricultural products are in the top three positions with the ranking of Chilean exports, accounting for approximately $25 \%$ of the total exports (Banco Central de Chile, 2020).

The agricultural sector in Chile is threatened by climate change (Meza et al., 2015; Mills-Novoa et al., 2016; Roco et al., 2016; del Pozo et al., 2019), land-use changes, as well as by the volatility of the international markets. Therefore, the investment in agricultural research and development $(R+D)$ should be an important strategy to strengthen the agriculture sector and maintain its competitiveness. But, how well prepared is the agricultural science in Chile in terms of institutions, human resources, investment and scientific productivity?

In this article we provide an overview of the agricultural sciences in Chile, starting with the historical events associated to the initiation of the agronomic science. We also describe the most relevant institutions, universities and research centers, and their associated human resources, current postgraduate (doctoral) programs, research and development (R+D) investment and scientific productivity and innovation. Finally, some conclusions and future perspectives are presented.

\section{HISTORY OF THE AGRICULTURAL SCIENCE IN CHILE}

The first attempts to improve agriculture in Chile was made by SNA with the creation of the first School of Agricultural Technician at Quinta Normal, Santiago, in 1851 (Table 1). Then, the Agricultural Institute of Chile was established in the same site in 1876, with the appointment of two foreign agricultural scientists, René Lefevre and Julio Besnard (Elgueta, 1982). The first cohort of Agricultural Engineers in Chile graduated in 1879. In 1881, with the creation of the first Agronomic Station of SNA at Quinta Normal, which was a small farm of 2.9 ha, the agricultural science was initiated, with the first studies aimed to facilitate adaptation of field crops such as wheat, barley, oat and several forages species (Elgueta, 1982).

The first School of Agronomy was created within Pontificia Universidad Católica de Chile in 1904, followed by the Faculty of Agronomy of Universidad de Chile in 1928, both in Santiago. In 1925, the SNA set up a new Experimental Station of 50 ha, outside but close to Santiago. This station was implemented with research facilities, including laboratories for chemistry, plant genetics, dairy and poultry production, and a specialized library. The release of the first improved varieties of wheat, maize and other crops by SNA was in 1928.

It was not until 1930 that the State of Chile started playing a significant role in the development of the agricultural science with the creation of the Department of Genetics and Crop Science of the Ministry of Agriculture (1930), along with the implementation of Experimental Stations along the country. With this landmark, plant breeding programs were initiated, allowing the development and release of the first wheat varieties developed from crosses. In 1984, the Department of Genetics and Crop Science was restructured, leading to the Department of Agricultural Research, with 19 Experimental Stations established between Vallenar and Osorno (a transect of $1300 \mathrm{~km}$ that covers a climatic gradient from semiarid to temperate humid), and a staff of 67 professionals, 23 of them with postgraduate training.

In the mid-1950, two new Faculties of Agronomy were created in the south of the country, by the Universidad de Concepción (in the city of Concepción, 1954) and the Universidad Austral (in the city of Valdivia, 1955). In 1957, a partnership between the Rockefeller Foundation and the Ministry of Agriculture of Chile lead to the development of the Special Studies Office, with the objective of boosting agricultural research in Chile. The Rockefeller Foundation started as a cooperative program for agriculture in Mexico in 1943, and 18 years later implemented similar programs in Colombia and Chile (Roberts, 1961). During that period, researchers from the USA were in charge of wheat breeding, pasture management and animal production programs. In 1959, this cooperative program created three Centers of Agricultural 
Table 1. Institutions and historical events associated to the initiation of the agricultural science in Chile.

\begin{tabular}{|c|c|c|}
\hline Year & Institution creation & Events \\
\hline 1838 & Sociedad Nacional de Agricultura (SNA) & First private association of farmers \\
\hline 1851 & School of Agriculture Technician of SNA, Quinta Normal, Santiago & An initiative of SNA \\
\hline 1876 & Agriculture Institute of Chile, Quinta Normal, Santiago & Two foreign scientists were appointed \\
\hline 1881 & Agronomic Station of SNA, Quinta Normal & Initiation of the agricultural science in Chile \\
\hline 1904 & Faculty of Agronomy, Universidad Católica de Chile & The first Faculty of Agronomy in Chile \\
\hline 1925 & Experimental Station "La Vega de Paine", created by SNA & $\begin{array}{l}\text { Experimental field of } 50 \text { ha and laboratories of } \\
\text { chemistry, plant genetics, dairy and poultry production, } \\
\text { and a library } \\
\text { Release of the first improved varieties (1928) }\end{array}$ \\
\hline 1928 & Faculty of Agronomy and Veterinary, Quinta Normal, Universidad de Chile & $\begin{array}{l}\text { Created in } 1927 \text { and incorporated to Universidad de } \\
\text { Chile in } 1928\end{array}$ \\
\hline 1930 & Department of Genetic and Crop Science, Ministry of Agriculture & New Experimental Stations in provinces \\
\hline 1948 & Department of Agriculture Research, Ministry of Agriculture & $\begin{array}{l}\text { Derived from the Department of Genetics and Crop } \\
\text { Science. Nineteen Experimental Stations were } \\
\text { established along the country }\end{array}$ \\
\hline 1954 & Faculty of Agronomy, Universidad de Concepción & $\begin{array}{l}\text { Third Faculty of Agronomy in Chile, and the first in } \\
\text { province }\end{array}$ \\
\hline 1955 & Faculty of Agronomy, Universidad Austral de Chile & \\
\hline 1957 & $\begin{array}{l}\text { Especial Studies Office, Rockefeller Foundation and Ministry of } \\
\text { Agriculture }\end{array}$ & $\begin{array}{l}\text { USA researchers leaded programs of wheat breeding, } \\
\text { pastures and animal production }\end{array}$ \\
\hline 1959 & $\begin{array}{l}\text { Three Centers of Agricultural Studies, with the funding of the Rockefeller } \\
\text { Foundation and the Government of Chile }\end{array}$ & $\begin{array}{l}\text { These were the Experimental Stations of La Platina } \\
\text { (Santiago), Quilamapu (Chillán) and Carillanca (Temuco) }\end{array}$ \\
\hline 1963 & Faculty of Agronomy, Universidad Católica de Valparaíso & \\
\hline 1964 & Instituto de Investigaciones Agropecuarias (INIA) & Initially with the three Experimental Station created in 1959 \\
\hline
\end{tabular}

Source: Elgueta (1982).

Science in Chile. In addition to experimental research, the program provided scholarships to pursue postgraduate studies in North American Universities and local training of agronomists in agricultural sciences. As a result, the first masters and doctorate fellows returned to the country by late 50s and early 60s. In 1964, the National Institute of Agriculture Research (INIA) was created, initially with three Experimental Stations, La Platina (Santiago), Quilamapu (Chillán) and Carillanca (Temuco), and incorporated the recently trained agronomists with postgraduate studies. At the beginning, INIA had 77 agronomists (16 masters and 4 doctors). Mr. Manuel Elgueta Guerin, a distinguished agronomist and geneticist was appointed as director between 1964 and 1970. The main research lines were soil science, crop science, animal production and horticulture. Additionally, it had an agricultural extension and seed production programs (INIA, 2015).

\section{INSTITUTIONS AND HUMAN RESOURCES}

INIA is still the main research institution in agricultural science in Chile, both in terms of area coverage and available human resources (Table 2). INIA has 10 Regional Research Centers across the country and 217 researchers (48\% with Ph.D.) and 252 professionals and technicians to support research activities. Only after 40 years, new Regional Centers in agricultural science, independent from INIA, were created under the initiative of National Agency of Research and Development (ANID former CONICYT) and the regional governments. Up to date, there are five new regional centers specialized in different aspects of agricultural science (Table 2). The number of researchers in these Regional Centers is far less than that of INIA, with a total of 40 scientist and 47 professionals and technicians.

Among the 20 schools of agriculture science existing in Chile, the Faculties of Agronomy of the Universidad de Chile and Pontificia Universidad Católica, both located in the capital, Santiago, are the oldest and the most important ones, in terms of faculty members ( 85 and 59 , respectively), concentrating $32 \%$ of the researchers in agricultural science. They are followed by the faculties of the Universidad de Concepción and Universidad Austral (first outside Santiago), with the second largest number of faculty members (47 and 36, respectively). After 1981, several regional universities (public and private) were established, leading to the development of new faculties in agricultural sciences, which at present are 20 in total, some of them with schools in more than one city (Table 2).

The private sector also contributes to the agricultural research and innovation in Chile. As mentioned before, the SNA had an experimental station and later cereal breeding program. In addition, Semillas Baer, founded in 1956, has been developing cultivars of wheat, oat, canola, lupins and quinoa, producing seeds of their respective cultivars for 
Table 2. Human resources associated with research in agriculture science.

\begin{tabular}{|c|c|c|c|c|c|c|}
\hline \multirow[b]{2}{*}{ Institution } & \multirow{2}{*}{$\begin{array}{l}\text { Year of } \\
\text { creation }\end{array}$} & \multirow{2}{*}{$\begin{array}{c}\text { Years of } \\
\text { accreditation }\end{array}$} & \multicolumn{3}{|c|}{ Researchers/Academic staff } & \multirow[b]{2}{*}{$\begin{array}{l}\text { Support professionals } \\
\text { and technicians }\end{array}$} \\
\hline & & & Ph.D. & M.Sc. & Bachelor & \\
\hline \multicolumn{7}{|l|}{ Research centers } \\
\hline Instituto de Investigaciones Agropecuarias (INIA) & 1964 & na & 89 & 64 & 64 & 252 \\
\hline $\begin{array}{l}\text { Centro de Genómica Nutricional Agroacuícola (CGNA), } \\
\text { La Araucanía }\end{array}$ & 2004 & na & 8 & - & - & 16 \\
\hline $\begin{array}{l}\text { Centro Regional de Estudios en Alimentos Saludables } \\
\text { (CREAS), Valparaíso }\end{array}$ & 2006 & na & 5 & - & - & 12 \\
\hline $\begin{array}{l}\text { Centro de Estudios Avanzados en Fruticultura (CEAF), } \\
\text { O'Higgins }\end{array}$ & 2009 & na & 6 & 1 & - & 12 \\
\hline $\begin{array}{l}\text { Centro de Estudios en Alimentos Procesados (CEAP), } \\
\text { Maule }\end{array}$ & 2009 & na & 3 & 1 & - & 5 \\
\hline $\begin{array}{l}\text { Centro Regional de Innovación para una agricultura } \\
\text { sostenible integral (Ceres), Valparaíso }\end{array}$ & 2011 & na & 4 & 1 & 11 & 2 \\
\hline Subtotal & & & 115 & 67 & 75 & 299 \\
\hline \multicolumn{7}{|l|}{ Universities with faculty or career in agriculture science } \\
\hline U. Católica & 1904 & 7 & 47 & 9 & 3 & - \\
\hline U. de Chile & 1928 & 7 & 61 & 16 & 8 & - \\
\hline U. de Concepción & 1954 & na & 31 & 11 & 6 & - \\
\hline U. Austral & 1955 & 6 & 30 & 4 & 2 & - \\
\hline U. Católica de Valparaíso & 1963 & 6 & 16 & 3 & - & - \\
\hline U. de Tarapacá & 1982 & 5 & 8 & 3 & 1 & - \\
\hline U. de Talca & 1983 & 7 & 20 & 2 & 1 & - \\
\hline U. de la Frontera & 1984 & 5 & 27 & 9 & 8 & - \\
\hline U. Mayor & 1989 & 6 & 11 & 20 & 6 & - \\
\hline U. de Las Américas & 1989 & 4 & ni & $\mathrm{ni}$ & $\mathrm{ni}$ & - \\
\hline U. Católica de Temuco & 1995 & 4 & 9 & 1 & - & - \\
\hline U. Católica del Maule & 1998 & 3 & 9 & 3 & - & - \\
\hline U. de La Serena & 2000 & 4 & 4 & 6 & 7 & - \\
\hline U. Santo Tomás & 2004 & 4 & ni & ni & ni & - \\
\hline U. Arturo Prat & 2000 & na & 8 & - & 1 & - \\
\hline U. Viña del Mar & 2003 & na & 3 & 5 & 1 & - \\
\hline U. de Magallanes & 2010 & na & 6 & 3 & 5 & - \\
\hline U. de O’Higgins & 2015 & na & 8 & - & - & - \\
\hline U. de Aysén & 2015 & na & 3 & - & 1 & - \\
\hline Subtotal & & & 301 & 95 & 50 & \\
\hline Total & & & 416 & 162 & 125 & 299 \\
\hline
\end{tabular}

farmers. In total, 66 seed companies are associated to the National Association of Seed Producers (ANPROS), although the majority carry out seed multiplication for foreign countries. Some of these companies, like Monsanto Chile, Pioneer Chile (now CORTEVA Agriscience), KWS Chile, DuPont Chile, ANASAC, Baer, among others, have a Department of R+D and perform plant breeding on different steps (e.g., advance of generation, evaluation of inbred and hybrids). Some Agrochemical companies (e.g., BASF Chile, Syngenta Chile, ANASAC, among others) perform evaluation of new pesticides, and also fertilizer companies (e.g., SQM, Ecofos) develop new formulation and fertilizer mixtures for different crops.

The number of agricultural researchers employed by the government, nonprofit and higher education agencies (excluding the private sector) has increased continuously from 1981 till 2013 at the rate of 11.2 researchers per year (Figure 1A). Of the 715 researchers in 2013, only 263 (37\%) had a doctoral degree and 310 (43\%) were only bachelor. Today, the percentage of bachelors working on research has been reduced to $18 \%$ (Table 2). Data of researchers in agricultural and veterinary science provide by OECD (2019) indicate that, in 2015-2016, there were 1000 researchers, but if we use the historical trend from the regression line of Figure 1A it is possible to extrapolate that agricultural scientists were $~ 780$ in 2018. Data of human resources involved in agricultural research at Research Centers and Schools of Agronomy (Table 2), plus the number of young researchers doing their doctoral thesis and postdocs (see below) corroborate this number. In addition, more than 300 support professionals and technicians are working in agricultural science (Table 2). 
Figure 1. Number of researchers in agricultural science in Chile (A) and comparison of the number of researchers per million inhabitants in Chile, Brazil and Argentina (B), between 1981 and 2013. Data from ASTI (2019). Broken line in A are data from OECD (2019) but includes veterinary science.
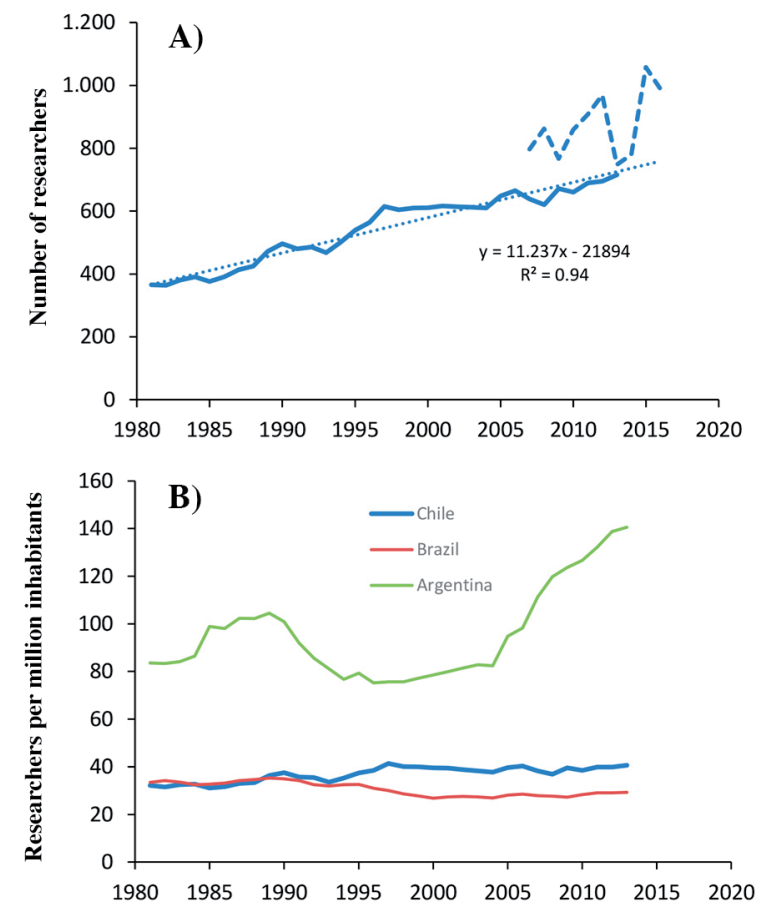

The number of researchers in agricultural science per million inhabitants in Chile (approximately 40) has been slightly higher than Brazil in the last two decades, but much lower than in Argentina (Figure 1B). Indeed, Chile has a very low number of researchers (in all disciplines) working in R+D; according to The World Bank data there were 446 researchers per million people in 2017, which is very low compared to OECD countries like Germany (5212 per million), UK (4600 per million), France (4715 per million), or Spain (3000 per million).

\section{POSTGRADUATE PROGRAMS}

The first doctoral program in agricultural science in Chile was offered by Universidad Austral in 1998 (Table 3). Shortly after, two more doctoral programs were launched in 2001, one as a joint program of four academic units (Agronomy, Veterinary, Forest Science and the Institute of Food Technology-INTA) of the University of Chile, and the other in Natural Resources, at Universidad de La Frontera, which includes soil science, plant nutrition and crop physiology, among other research lines. During the same decade, other two universities created doctoral programs in agricultural science, Pontificia Universidad Católica de Chile in 2003 and Universidad de Talca in 2005. After 2010, six new doctoral programs in agricultural science were launched: Universidad de Concepción (2013), which was a new version of a joint doctoral program created in 2003, Universidad Católica de Temuco (2015) and Universidad de La Frontera (2017). The most recently created ones are the doctoral program in Plant Biotechnology, associated to the Faculty of Agronomy of the Universidad Católica de Chile, that was initiated in 2018, and the doctoral program in Water Resources and Energy for Agriculture of the Universidad de Concepción, which was an updated version of the doctoral program in Agricultural Engineering created in 2001.

Accreditation by the National Commission on Accreditation (CNA) is an important issue for postgraduate programs in Chile, as doctoral students of credited institutions are eligible for ANID scholarships. All the doctoral programs (11) are accredited but only three have six or more years (Table 3): Natural Resources Science of Universidad de La Frontera (8 yr), Agricultural Science of Universidad de Talca (6 yr) and Agriculture Sciences of Universidad Austral (6 yr). 
Table 3. Doctoral programs in Agriculture Sciences in Chile, years accreditation by National Commission on Accreditation and number of graduated students between 2014 and 2018.

\begin{tabular}{|c|c|c|c|c|}
\hline Doctoral program & University & $\begin{array}{l}\text { Year of } \\
\text { initiation }\end{array}$ & $\begin{array}{l}\text { Accreditation } \\
\text { years }^{1}\end{array}$ & $\begin{array}{l}\text { Graduated students } \\
\quad(2014-2018)\end{array}$ \\
\hline Ciencias Agrarias & Austral & 1998 & $6(2019)$ & 16 \\
\hline Ciencias de Recursos Naturales & La Frontera & 2001 & $8(2016)$ & 37 \\
\hline Ciencias Silvo-Agropecuarias y Veterinarias & Chile & 2001 & $3(2018)$ & 63 \\
\hline Ciencias de la Agricultura & Católica, Santiago & 2003 & $3(2017)$ & 35 (2013-2017) \\
\hline Ciencias Agrarias & Talca & 2005 & $6(2015)$ & 20 \\
\hline Ciencias de la Agronomía & Concepción & 2013 & $3(2018)$ & 4 \\
\hline Ciencias Agropecuarias & Católica, Temuco & 2015 & $4(2019)$ & nc \\
\hline Ciencias Agroalimentarias & La Frontera & 2017 & $3(2018)$ & nc \\
\hline Ciencias Agroalimentarias & Católica, Valparaíso & 2017 & $3(2019)$ & nc \\
\hline Biotecnología Vegetal & Católica, Santiago & 2018 & $3(2019)$ & nc \\
\hline Recursos Hídricos y Energía para la Agricultura & Concepción & 2018 & $2(2019)$ & nc \\
\hline
\end{tabular}

Source: Data were obtained from the doctoral program web pages and the National Commission on Accreditation.

${ }^{1}$ In brackets the year of the most recent accreditation.

nc: No cohort of graduated.

Graduate students are the main source of new researchers in agricultural science. These new cadre of scientists come from national and foreign doctoral programs. Students apply for ANID scholarship to study in Chile or abroad in one of the top 150 universities of the world. The number of graduated students in agricultural science in Chile during the period 2014-2018 was 175.

Some of the graduated students applied to a postdoc funded by National Fund for Scientific and Technological Development (Fondecyt) from ANID to continue their training as scientists, for a 3-yr period. The number of postdocs in agriculture science has been 74 between 2014 (17) and 2018 (13), which represented only 5\% of the postdocs financed by Fondecyt.

\section{INVESTMENT IN R+D AND INNOVATION}

Public investment in agricultural $\mathrm{R}+\mathrm{D}$ (including salary-related expenses, program operating costs, and capital investments) has increased from less than US\$100 million in the early eighties to US\$230 million in 1997; after this year there was a decline till 2006 and then a recuperation, reaching US\$190 million in 2013 (Figure 2A). Compared to Brazil and Argentina, national expenditure in agricultural science (per million population) in Chile between 1981 and 2013 has been in general lower, with the exception of the period between 1996 and 2002 (Figure 2B). Total expenditure in R+D (all disciplines) in Chile was US $\$ 924$ million in 2016, representing only $0.38 \%$ of gross national product (GNP) being, by far, the lowest among the OECD countries (average 2.37\%).

The Ministry of Agriculture provides resources for $\mathrm{R}+\mathrm{D}$, through direct transfers to INIA (US\$26 million in 2017) and for innovation through Agriculture Innovation Foundation (FIA; US\$16.5 million in 2017); FIA finances applied research, innovation and extension initiatives for the agricultural sector, as well as technological visits to facilitate technology transfer and sharing innovation experiences, seminars and training courses, and diffusion of technologies. Also, ANID finances R+D projects in agriculture science through Fondecyt programs (Regular: for researchers with a demonstrated trajectory; Initiation in research: for new researchers; and Post-doctorate: for researchers that have obtained a doctorate degree in the last three years), the Scientific and Technological Development Support Fund (Fondef), ANILLO programs, among others. In addition, there are some resources to agricultural R+D that come from the Ministry of Economy through the program Innova-CORFO (Production Development Corporation) and Innovation and Competitiveness Fund (FIC), which is managed by regional governments. Fondecyt programs are oriented to develop basic scientific and technological research, while Innova and FIC focus on applied science and innovation with transferable results as main outcome within the period of the project (typically $3 \mathrm{yr}$ ). Fondef supports applied R+D projects with a high scientific background, aimed at generating economic and social impacts, in a maximum of 4 yr divided in two stages: in the first one ( $2 \mathrm{yr})$ the objective is producing basic knowledge of a specific innovation that, if successful, can be validated in the second stage ( $2 \mathrm{yr}$ ). The Universities trough their Faculties in Agriculture Science contribute with human resources (academic and support staff) and infrastructure (labs and experimental fields), and also with small budgets for research. 
Figure 2. Expenditure (in purchasing power parity) in agricultural research in Chile (A) and comparison of the spending per million inhabitants in Chile, Brazil and Argentina (B), between 1981 and 2013. Data from ASTI (2019). Dotted line in A are data from OECD (2019) but includes veterinary science.
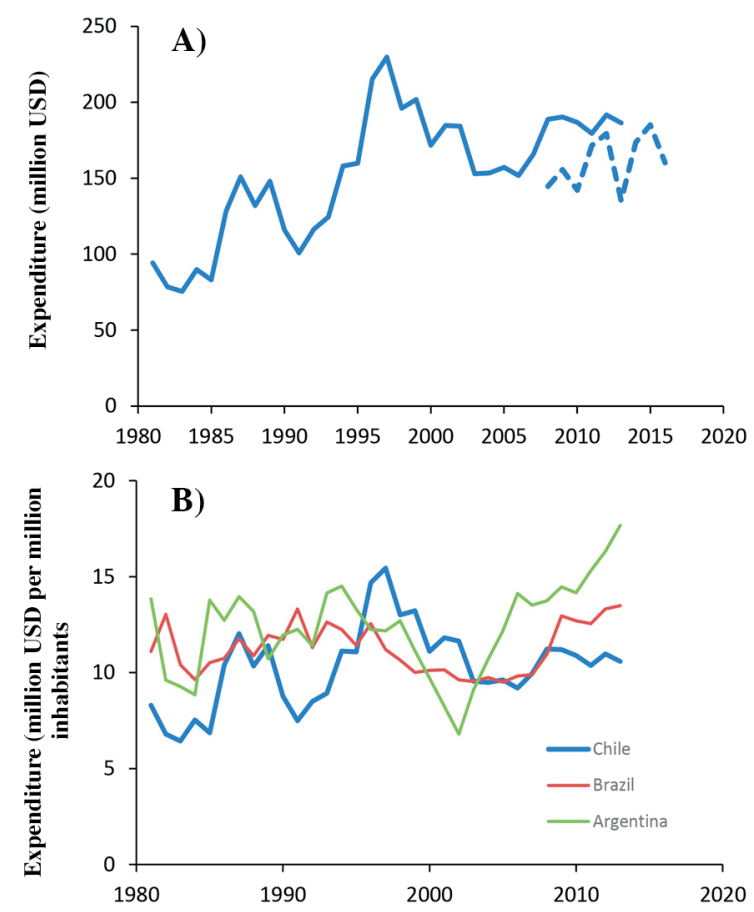

\section{Research and development projects}

A summary of $\mathrm{R}+\mathrm{D}$ projects, over the period 2014 to 2018 classified by funding source and category of productive activity, is presented in Table 4. Overall, 698 projects in agricultural science were funded in a 5 years period, where orchards (including vineyard) represented $40 \%$ of projects, consistent with the importance that fruit products and wine has in the export products. Annual crops, animal science, horticulture and grasslands account for $13 \%, 12 \%, 11 \%$ and $5 \%$ of the projects, respectively. Soil science and pest and diseases represented a small percentage (3\% and $4 \%$, respectively) of the projects. A similar trend is observed when looking at the funding sources individually. Analyzing the projects by funding source, the largest number is associated to Fondecyt with an average of 51.6 projects per year between 2014 to 2018, followed by FIC, Innova and FIA with 35, 30 and 17.6 projects, respectively, whereas Fondef financed in average 6.6 project per year (Table 4). However, looking at the trend over the 5 years period (2014-2018), none of the funding agencies show a trend to increase the number of financed projects and, in some of them (e.g., Fondef), there has been a clear reduction (Table 4). Only Fondecyt evidence consistence in terms of the number of projects financed every year in agricultural science.

It is relevant to mention that the rate of approval of projects varies according to the funding source; in the case of Fondecyt it has declined from 45\% in 2014 to about 30\% in the last years (a clear sign that demand for funding has increased), while in the case of Fondef and FIA the rate of approval is much lower $(<20 \%)$, revealing that there is still a large capacity to produce research in the country with more available resources.

\section{SCIENTIFIC PRODUCTIVITY}

Analysis of scientific publications was performed using Scopus database and considering the period 2014-2019. Search criteria used were: i) crop; ii) orchard OR vineyard OR wine; iii) horticulture OR vegetable; iv) grassland OR pasture; v) animal production (cattle, sheep, pork and poultry); and vi) agricultural OR all the above-mentioned search criteria, as well as at least one of the authors having Chile as affiliation country. Articles of disciplines like soil science or crop protection are included in the above searching categories. The larger number of articles were obtained under the category "crop" (average 138 per year), but this search criterion does not only include field crops, but also some articles of other 
categories, such as orchards and vegetables (Table 5). The second largest number of articles belonged to orchard, vineyard and wine (average 103), followed by animal production (60), horticulture (52) and grassland (45). It must be mentioned that articles of these five categories cannot be added to get the total number per year, because there is some overlapping (i.e., an article could appear in more than one search category). Thus, using all the search criteria mentioned above

Table 4. Number of projects of research and development (and innovation) in Agriculture Science in Chile between 2014 and 2018, according to funding programs.

\begin{tabular}{|c|c|c|c|c|c|c|c|c|c|}
\hline Year & Crops & Orchards & Horticulture & Grassland & $\begin{array}{l}\text { Animal } \\
\text { science }\end{array}$ & $\begin{array}{c}\text { Soil } \\
\text { science }\end{array}$ & $\begin{array}{l}\text { Pest and } \\
\text { diseases }\end{array}$ & Others & Total \\
\hline \multicolumn{10}{|c|}{ Fondecyt } \\
\hline 2014 & 8 & 22 & 3 & 6 & 12 & 5 & 8 & 1 & 65 \\
\hline 2015 & 6 & 17 & 2 & 2 & 6 & 5 & 1 & 4 & 42 \\
\hline 2016 & 7 & 20 & 3 & 2 & 11 & 6 & 2 & 1 & 52 \\
\hline 2017 & 11 & 14 & 3 & 3 & 5 & 2 & 5 & 4 & 47 \\
\hline 2018 & 5 & 18 & 4 & 4 & 8 & 4 & 5 & 4 & 52 \\
\hline \multicolumn{10}{|c|}{ Fondef } \\
\hline 2014 & 1 & 3 & 1 & - & 5 & - & 2 & 1 & 13 \\
\hline 2015 & - & 6 & - & - & 2 & - & 1 & - & 9 \\
\hline 2016 & - & 2 & 1 & - & - & - & - & - & 3 \\
\hline 2017 & - & 3 & - & - & 1 & - & - & - & 4 \\
\hline 2018 & - & 1 & - & - & - & - & - & 3 & 4 \\
\hline \multicolumn{10}{|l|}{ FIA } \\
\hline 2014 & 2 & 8 & 4 & - & 2 & - & - & 2 & 18 \\
\hline 2015 & 6 & 12 & 4 & - & 2 & - & - & - & 24 \\
\hline 2016 & 6 & 13 & 2 & 1 & 1 & - & - & 1 & 24 \\
\hline 2017 & 1 & 4 & 1 & - & 1 & - & - & 1 & 8 \\
\hline 2018 & 3 & 3 & 1 & 2 & 4 & - & - & 1 & 14 \\
\hline \multicolumn{10}{|c|}{ Innova } \\
\hline 2014 & 6 & 25 & 4 & 4 & 3 & - & - & 7 & 49 \\
\hline 2015 & 10 & 44 & 10 & 3 & 10 & - & - & 23 & 100 \\
\hline 2016 & - & - & - & - & - & - & - & 1 & 1 \\
\hline 2017 & - & - & - & - & - & - & - & - & - \\
\hline 2018 & - & - & - & - & - & - & - & - & - \\
\hline \multicolumn{10}{|c|}{ FIC/FIC Regional/FIC CORFO/FIC-FIA } \\
\hline 2014 & 3 & 14 & 6 & 1 & 3 & - & - & 9 & 36 \\
\hline 2015 & 5 & 17 & 9 & 6 & 4 & - & - & 13 & 54 \\
\hline 2016 & 6 & 20 & 11 & 1 & 2 & - & 2 & 4 & 46 \\
\hline 2017 & 4 & 15 & 11 & 0 & 3 & - & - & 6 & 39 \\
\hline 2018 & ni & ni & n.i. & ni & ni & ni & ni & ni & ni \\
\hline Total & 90 & 281 & 80 & 35 & 85 & 22 & 26 & 79 & 698 \\
\hline
\end{tabular}

Source: National data base project of FIA (http://aplicaciones.fia.cl:8080/sigesfia/bdn/bdn.aspx).

Fondecyt: National Fund for Scientific and Technological Development; Fondef: Scientific and Technological Development Support Fund; FIA: Agriculture Innovation Foundation; FIC: Innovation and Competitiveness Fund; CORFO: Production Development Corporation ni: No information.

Table 5. Scopus publications in Agriculture Science in Chile between 2014 and 2019, according to five search categories. Articles concerning pest and diseases, and soil science are included in the five categories.

\begin{tabular}{ccccccc}
\hline Year & Crop & $\begin{array}{c}\text { Orchard OR } \\
\text { vineyard OR wine }\end{array}$ & $\begin{array}{c}\text { Horticulture OR } \\
\text { vegetable }^{1}\end{array}$ & $\begin{array}{c}\text { Grassland OR } \\
\text { pasture }\end{array}$ & $\begin{array}{c}\text { Animal } \\
\text { production }^{2}\end{array}$ & $\begin{array}{c}\text { All } \\
\text { articles }^{3}\end{array}$ \\
\hline 2014 & 120 & 120 & 54 & 42 & 57 & 317 \\
2015 & 116 & 90 & 51 & 42 & 58 & 317 \\
2016 & 153 & 95 & 44 & 58 & 61 & 370 \\
2017 & 127 & 127 & 53 & 30 & 55 & 377 \\
2018 & 135 & 98 & 49 & 46 & 63 & 355 \\
2019 & 175 & 90 & 59 & 51 & 65 & 447 \\
\hline Total & 826 & 620 & 310 & 269 & 359 & 2183 \\
\hline
\end{tabular}

${ }^{1}$ Excluded medicine.

${ }^{2}$ Cattle OR sheep OR pork OR poultry (excluded medicine and veterinary science).

${ }^{3}$ All the search criteria OR agricultural. 
plus the word "agricultural" it was possible to get the maximum number of articles in agricultural science, which was on average 364 per year (Table 5). The number of articles per year were similar in 2014 and 2015, raised by 16.7\% in 2016 and then had an important increased in 2019 (Table 5). If the actual number of agricultural researchers (included in doctoral student and post docs) was about 1000 in 2019, the productivity can be estimated as $\sim 0.45$ article per researcher.

\section{FUTURE PERSPECTIVES}

The overview of the current status of institutions, human resources and capacity building for agricultural R+D showed that although significant progress has been made the last decades, there still a reduced number of researcher and insufficient investment to face urgent challenges of the agriculture sector in Chile. $R+D$ is essential for a successful agriculture and securing food (Beintema and Stads, 2008; Hellin and Camacho, 2017). Investment in R+D has proved to be highly profitable; Jin and Huffman (2016) estimated a social rate of return of investment in agricultural science of 67\% and Wang et al. (2012) a rate of $45 \%$, both studies were done with USA data. In addition, the return of investment in extension were estimated in over 100\% (Huffman and Evenson, 2006; Jin and Huffman, 2016).

This is particularly important in Chile, where agriculture needs to adapt its productive systems to cope with higher temperatures and water scarcity, and also, it should be able to deliver food with more sustainable practices. In addition, Chile is exposed to foreign competitors that have been increasing their markets shares in detriment to Chilean exports (Pérez and Valdés, 2019). Therefore, the agri-food system depends as a central piece of $\mathrm{R}+\mathrm{D}$ institutions for fostering development and competitiveness (Zilberman et al., 2017; Reardon at al., 2019), but also to serve as a network broker among the system agents (producers, input providers, buyers, etc.) (Klerkx et al., 2009).

Along with a higher investment in $\mathrm{R}+\mathrm{D}$, more attention should be paid to addressing the gap between the generation of scientific evidence and its dissemination in a user-oriented fashion. Innovation is increasingly seen as the outcome of a coordinated effort among different stakeholders (Den Boer et al., 2021; Krishnan et al., 2021), and a bottom-up transformation (Sandhu, 2021) to tackle complex productive, social and environmental problems and transform knowledge into actions taken by the public and private sector.

\section{CONCLUSIONS}

The main research institution, INIA, has a reduced number of researchers considering the extension of the territory and diversity of crops, disciplines, and environments. However, the number of schools of agriculture (20) and doctoral programs (11) in agriculture science is relatively high for a population of about 18 million. Public investment in agricultural $\mathrm{R}+\mathrm{D}$ (per million population) in the last decade has been lower than in Brazil or Argentina. Also, the number of researchers in agricultural science $(<45$ per million of inhabitants; $\sim 800$ in total) and the scientific productivity per researcher $(<0.45$ articles Scopus) is reduced to face urgent challenges of the agricultural sector in Chile.

\section{REFERENCES}

ASTI. 2019. Open-access data and analysis on agricultural research investment and capacity in low- and middle-income countries. Available at https://www.asti.cgiar.org/data. Agricultural Science and Technology Indicators (ASTI), International Food Policy Research Institute (IFPRI), Washington, D.C., USA.

Banco Central de Chile. 2020. Estadísticas de exportaciones. Available at https://si3.bcentral.cl/siete/secure/cuadros/arboles. aspx. Banco Central de Chile, Santiago, Chile.

Beintema, N.M., and Stads, G.J. 2008. Measuring agricultural research investments: A revised global picture. ASTI Background Note, October 2008. Available at https://www.asti.cgiar.org/pdf/Global_revision.pdf. Agricultural Science and Technology Indicators (ASTI), International Food Policy Research Institute (IFPRI), Washington, D.C., USA.

del Pozo, A., Brunel-Saldias, N., Engler, A., Ortega-Farias, S., Acevedo-Opazo, C., Lobos, G.A., et al. 2019. Climate change impacts and adaptation strategies of agriculture in Mediterranean-climate regions (MCRs). Sustainability 11(10):2769. doi:10.3390/su11102769.

Den Boer, A.C.L., Kok, K.P.W., Gill, M., Breda, J., Cahill, J., Callenius, C., et al. 2021. Research and innovation as a catalyst for food system transformation. Food Science and Technology 107:150-156. doi:10.1016/j.tifs.2020.09.021. 
Elgueta, M. 1982. La investigación agrícola en Chile: Evolución histórica. p. 109-140. En Elgueta, M., y Venezian, E. (eds.) Economía y organización de la investigación agropecuaria [Online]. Instituto de Investigaciones Agropecuarias (INIA), Instituto Interamericano de Ciencias Agrícolas (IICA), Universidad de Chile, Facultad de Ciencias Agrarias, Veterinarias y Forestales; Pontificia Universidad Católica de Chile, Facultad de Agronomía, Santiago, Chile.

Hellin, J., and Camacho, C. 2017. Agricultural research organizations' role in the emergence of agricultural innovation systems. Development in Practice 27:111-115.

Huffman, W.E., and Evenson, R.E. 2006. Science for Agriculture: A long-term perspective. Blackwell Publishing, Ames, Iowa, USA.

INIA. 2015. 50 Años del Instituto de Investigaciones Agropecuarias. Liderando el desarrollo de la agricultura de Chile. Available at http://www.inia.cl/wp-content/uploads/2018/03/INIA-50-A\%C3\%91OS-Liderando-el-Desarrollo-de-la-Agricultura-deChile.pdf. Instituto de Investigaciones Agropecuarias (INIA), Santiago, Chile.

INIA. 2018. Memoria 2018. Available at http://wwwsp.inia.es/Publicaciones/PublicacionesInstitucionales/Documents/ Memoria2018.pdf. Instituto de Investigaciones Agropecuarias (INIA), Santiago, Chile.

Jin, Y., and Huffman, W.E. 2016. Measuring public agricultural research and extension and estimating their impacts on agricultural productivity: new insights from U.S. evidence. Agricultural Economics 47:15-31.

Klerkx, L., Hall, A., and Leeuwis, C. 2009. Strengthening agricultural innovation capacity: are innovation brokers the answer? International Journal of Agricultural Resources, Governance and Ecology 8(5/6):409-438.

Krishnan, R., Yen, P., Agarwal, R., Arshider, K., and Bajada, C. 2021. Collaborative innovation and sustainability in the food supply chai- evidence from farmers producer organizations. Resources, Conservation \& Recycling 168:105253.

Meza, F.J., Vicuña, S., Gironás, J., Poblete, D., Suárez, F., and Oertel, M. 2015. Water food energy nexus in Chile: the challenges due to global change in different regional contexts. Water International 40:5-6, 839-855.

Mills-Novoa, M., Pszczolkolski, P., and Meza, F.J. 2016. The impact of climate change on the viticultural suitability of Maipo valley, Chile. Professional Geographer 68(4):561-573.

ODEPA. 2019. Panorama de la agricultura chilena. Available at https://www.odepa.gob.cl/wp-content/uploads/2019/09/ panorama2019Final.pdf. Oficina de Estudios y Planificación Agraria (ODEPA), Santiago, Chile.

OECD. 2019. OECD.Stats. Available at https://stats.oecd.org. Organisation for Economic Co-operation and Development (OECD), Paris, France.

Pérez, R., y Valdés, A. 2019. Análisis de la evolución y desempeño agroexportador de Chile, 2000-2017. Available at https://www.odepa.gob.cl/wp-content/uploads/2019/04/EvolucionAgroExp.pdf. Oficina de Estudios y Planificación Agraria (ODEPA), Santiago, Chile.

Reardon, T., Echeverría, R., Berdegué, J., Minten, B., Liverpool-Tasie, S., Tshirley, D., et al. 2019. Rapid transformation of food systems in developing regions: highlighting the role of agricultural research \& innovations. Agricultural Systems 172:47-59.

Roberts, L.M. 1961. The Rockefeller foundation program in the agricultural sciences. Economic Botany 15(4):296-301. https://doi.org/10.1007/BF02907850.

Roco, L., Poblete, D., Kerrigan, G., and Meza, F.J. 2016. Understanding farmers' decision to cope with drought and water scarcity: Case studies from two river basins of Chile in the context of Climate Change. Environmental Management 58(6):958-971.

Rothamsted. 2019. The history of Rothamsted Research. Available at https://www.rothamsted.ac.uk/history-and-heritage. Rothamsted Research, Harpenden, Hertfordshire, UK.

Sandhu, H. 2021. Bottom-up transformation of agriculture and food systems. Sustainability 13:2171.

SNA. 2014. Historia de la institución. Sociedad Nacional de Agricultura (SNA), Santiago, Chile. Available at http://www.sna.cl/historia (accessed 29 October 2014).

Wang, S.L., Ball, V.E., Fulginiti, L.E., and Plastina, L.E. 2012. Accounting for the impact of local and spill-in public research, extension and roads on US regional agricultural productivity, 1980-2004. p. 13-32. In Fuglie, K.O., Wang, S.L., Ball, V.E. (eds.) Productivity growth in agriculture: An international perspective. CABI, Cambridge, Massachusetts, USA.

Zilberman, D., Lu, L., and Reardon, T. 2017. Innovation-induced food supply chain design. Food Policy 83:289-297. http://dx.doi.org/10.1016. 